\title{
PENGARUH MOTIVASI SISWA DAN KREATIVITAS BELAJAR TERHADAP HASIL BELAJAR PKn SISWA
}

\author{
Teguh Wiyono \\ STKIP ARAHMANIYAH DEPOK \\ Email : wiyonoteguh04@gmail.com
}

Naskah diterima: 06/09/2018 revisi: 31/10/2018 disetujui: 31/10/2018

\begin{abstract}
Abstrak
Penelitian ini bertujuan untuk mengetahui Pengaruh motivasi siswa dan kreativitas belajar terhadap hasil belajar PKn siswa. Metode yang digunakan adalah penelitian survey yang berproses kuantitatif dengan pendekatan eksplanasi asosiatif kausal, melalui sampel acak sebanyak 30 responden siswa kelas XI dari populasi sebanyak 140 siswa kelas XI SMK Swasta Di Kecamatan Cibinong Kabupaten Bogor. Hasil penelitian menunjukan bahwa Motivasi Siswa dan kreativitas belajar secara bersama-sama berpengaruh cukup terhadap Hasil Belajar di SMK Swasta di Kecamatan Cibinong Kabupaten Bogor, dengan nilai korelasi sebesar 0,723. Besarnya pengaruh motivasi siswa dan kreativitas belajar terhadap hasil belajar siswa yakni mencapai sekitar 52,20\%. Melihat besarnya pengaruh motivasi siswa dan kreatifitas belajar terhadap hasil belajar maka guru dan orang tua hendaknaya selalu memotivasi siswa dan memacu kreatifitasnya dalam belajar guna meningkatkan hasil belajarnya.
\end{abstract}

Kata kunci: Motivasi; kreatifitas belajar; hasil belajar

\section{THE INFLUENCE OF STUDENT MOTIVATION AND CREATIVITY LEARNING TO STUDENT RESULTS}

\begin{abstract}
This study aims to determine the effect of student motivation and learning creativity on student learning outcomes. The method used is quantitative research with quantitative explanation approach causal causal explanation, through a random sample of 30 class XI students of the population of 140 students class XI SMK Private In Cibinong District Bogor Regency. The results showed that student motivation and creativity of learning together influence enough on the Results Learning in Private SMK in District Cibinong Bogor Regency, with a correlation of 0.723. The amount of influence of students' motivation and creativity of learning on student learning outcomes reaches about 52.20\%. Seeing the magnitude of the influence of student motivation and creativity to learn the results of learning then teachers and parents should always motivate students and spur their creativity in learning to improve learning outcomes.
\end{abstract}

Keywords: Motivation; creativity learning; student result 


\section{PENDAHULUAN}

Perkembangan dan kemajuan suatu bangsa sangat dipengaruhi oleh mutu pendidikan. Pendidikan menurut bentuknya dibedakan menjadi dua, yaitu pendidikan formal dan pendidikan non formal. Pendidikan formal adalah pendidikan yang berlangsung secara teratur, bertingkat dan berkesinambungan, sedangkan pendidikan non formal adalah pendidikan yang dilakukan secara tertentu tetapi tidak mengikuti peraturan yang ketat. Sebagai penyelenggara pendidikan formal, sekolah mengadakan kegiatan secara berjenjang dan berkesinambungan. Di samping itu, sekolah juga berusaha semaksimal mungkin untuk meningkatkan prestasi belajar anak didiknya.

Berbicara masalah belajar sangatlah luas. Sekolah sebagai pihak pengelola pendidikan telah melakukan berbagai usaha untuk memperoleh kualitas dan kuantitas pendidikan dalam rangka meningkatkan prestasi belajar siswa, yang selanjutnya terwujudlah perubahan-perubahan dalam pengorganisasian kelas, penggunaan metode belajar, strategi belajar mengajar, dan bertindak selaku fasilitas untuk menciptakan kondisi proses pembelajaran yang efektif.

Keberhasilan dalam pendidikan dipengaruhi oleh beberapa faktor. Faktorfaktor tersebut dapat dikelompokkan menjadi dua yaitu faktor dari dalam atau internal dan faktor dari luar atau eksternal. Beberapa faktor dari dalam siswa diperkirakan dapat mempengaruhi keberhasilan dalam pendidikan adalah kreativitas siswa.

Melalui usaha pendidikan diharapkan kualitas generasi muda yang cerdas dan kreatif. Selain kecerdasan, kreativitas juga diperlukan siswa dalam mencapai prestasi belajar. Namun kenyataannya kreativitas siswa sekarang ini berkembang lambat dan frekuensi belajar siswa yang kurang. Hal ini dikarenakan sistem pendidikan yang senantiasa bergantung pada pendidik. Akibatnya siswa kurang bersemangat untuk mencapai prestasi belajar yang tinggi. Siswa kurang memiliki tingkah laku yang kritis bahkan cara berpikir untuk mengeluarkan ide-ide yang sifatnya inovatif pun terkesan lambat.

Dulu orang biasanya mengartikan anak berbakat sebagai anak yang memiliki tingkat kecerdasan yang tinggi. Namun, sekarang makin disadari bahwa yang menentukan keberbakatan bukan hanya inteligensi melainkan juga kreativitas untuk berprestasi. Kreativitas adalah kemampuan untuk mengembangkan imaginasi dalam berpikir konstruktif. Seseorang dikatakan mempunyai daya kreasi yang tinggi bilamana ia mampu menemukan serta menggabungkan gagasan/ide-ide atau pemikiran baru yang orisinil dan dalam kombinasi yang baru. Ia tidak terpengaruh oleh pemikiran maupun cara orang lain, namun dengan daya kreasinya ia mampu mengembangkan alternatif lain yang lebih berani.

Dalam upaya peningkatan kualitas pembelajaran berbagai upaya dilakukan yaitu dengan peningkatan motivasi belajar. Dalam hal belajar siswa akan berhasil kalau dalam dirinya sendiri ada kemauan dan kesadaran untuk belajar dan keinginan atau dorongan untuk belajar, karena dengan peningkatan motivasi siswa dalam belajar maka siswa akan tergerak, terarahkan sikap dan perilaku siswa dalam belajar.

Dalam motivasi siswa dalam belajar terkandung adanya cita-cita atau aspirasi siswa, ini diharapkan siswa mendapat motivasi belajar sehingga mengerti dengan apa yang menjadi tujuan dalam belajar. Di samping itu, keadaan siswa yang baik dalam belajar akan menyebabkan siswa tersebut bersemangat dalam belajar dan mampu menyelesaikan tugas dengan baik, kebalikan dengan siswa yang sedang sakit, ia tidak mempunyai gairah dalam belajar.

Motivasi bukan saja penting karena menjadi faktor penyebab belajar, namun juga memperlancar belajar dan mempengaruhi hasil belajar. Secara 
historik, guru selalu mengetahui kapan siswa perlu diberi motivasi selama proses belajar, sehingga aktivitas belajar berlangsung lebih menyenangkan, arus komunikasi lebih lancar, menurunkan kecemasan siswa, meningkatkan kreativitas dan aktivitas belajar.

Pembelajaran yang diikuti oleh siswa yang termotivasi akan benar-benar menyenangkan, terutama bagi guru. Siswa yang menyelesaikan tugas belajar dengan perasaan termotivasi terhadap materi yang telah dipelajari, mereka akan lebih mungkin menggunakan materi yang telah dipelajari. Berkaitan dengan hal itu guru hendaknya membangkitkan motivasi siswa dalam belajar karena tanpa motivasi, hasil belajar yang dicapai akan minimum sekali. Agar hasil yang diajarkannya tercapai secara optimal maka seorang guru harus menganggap bahwa siswa-siswa yang dihadapinya tidak akan mudah menerima pelajaran yang diberikannya itu. Dalam hal ini guru dapat memaksimalkan peranya sebagai motivator (Feriandi, 2017; Marzuki \& Feriandi, 2016)

Motivasi siswa dalam belajar akan menjadi lemah, lemahnya motivasi atau tidak adanya motivasi siswa dalam belajar akan melemahkan kegiatan, sehingga mutu hasil belajar akan menjadi rendah. Oleh karena itu, motivasi belajar pada diri siswa perlu diperkuat terus menerus. Dengan tujuan agar siswa memiliki motivasi belajar yang kuat, sehingga hasil belajar yang diraihnyapun dapat optimal.

Motivasi siswa dalam belajar yang dimiliki siswa-siswa dalam setiap kegiatan pembelajaran sangat berperan untuk meningkatkan hasil belajar siswa dalam mata pelajaran tertentu. Siswa-siswi tersebut akan dapat memahami apa yang dipelajari dan dikuasai serta tersimpan dalam jangka waktu yang lama. Siswa menghargai apa yang telah dipelajari hingga merasakan kegunaannya didalam kehidupan sehari-hari di tengah-tengah masyarakat.
Siswa yang bermotivasi tinggi dalam belajar memungkinkan akan memperoleh hasil belajar yang tinggi pula, artinya semakin tinggi motivasinya, semakin intensitas usaha dan upaya yang dilakukan, maka semakin tinggi hasil belajar yang diperolehnya. Siswa melakukan berbagai upaya atau usaha untuk meningkatkan keberhasilan dalam belajar sehingga mencapai keberhasilan yang cukup memuaskan sebagaimana yang diharapkan. Di samping itu motivasi juga menopang upaya-upaya dan menjaga agar proses belajar siswa tetap jalan. Hal ini menjadikan siswa gigih dalam belajar.

Jika motivasi siswa untuk berhasil lebih kuat daripada motivasi untuk tidak gagal, maka ia akan segera memerinci kesulitan-kesulitan yang dihadapinya. Sebaliknya ia akan mencari soal yang lebih mudah atau bahkan yang lebih sukar. Siswa yang memiliki motivasi untuk berhasil akan bekerja lebih keras daripada orang yang memiliki motivasi untuk tidak gagal. Dengan demikian siswa yang memiliki motivasi untuk berhasil harus diberi pekerjaan yang menantang dan sebaliknya jika siswa yang memiliki motivasi untuk tidak gagal sebaiknya diberi pekerjaan yang kira-kira dapat dikerjakan dengan hasil yang baik.

Apabila motif atau motivasi belajar timbul setiap kali belajar, besar kemungkinan hasil belajarnya meningkat. Banyak bakat siswa tidak berkembang karena tidak memiliki motif yang sesuai dengan bakatnya itu. Apabila siswa itu memperoleh motif sesuai dengan bakat yang dimilikinya itu, maka lepaslah tenaga yang luar biasa sehingga tercapai hasil-hasil belajar yang semula tidak terduga. Mengenai pengaruh motivasi dengan prestasi belajar, kajian yang dilakukan oleh Soenarjo, dkk (2017), yang mana pada penelitian tersebut menjelaskan bahwa prestasi belajar dipengaruhi oleh motivasi belajar sebesar $4,8 \%$. 
$\begin{array}{ccc}\text { Kreativitas } & \text { seringkali dianggap } \\ \text { sebagai } \quad \text { sesuatu keterampilan yang }\end{array}$ didasarkan pada bakat alam, dimana hanya mereka yang berbakat saja yang bisa menjadi kreatif. Anggapan tersebut tidak sepenuhnya benar, walaupun dalam kenyataannya terlihat bahwa orang tertentu memiliki kemampuan untuk menciptakan ide, gasasan baru dengan cepat dan beragam. Sesungguhnya kemampuan berpikir kreatif pada dasarnya dimiliki oleh semua orang.

Kreativitas merupakan suatu proses mental individu yang melahirkan gagasan, proses, metode ataupun produk baru yang efektif yang bersifat imajinatif, fleksibel, suksesi, dan diskontinuitas, yang berdaya guna dalam berbagai bidang untuk pemecahan suatu masalah. Jadi kreativitas merupakan bagian dari usaha seseorang guru untuk mengembangkan pembelajaranya (Suprihatin, 2017). Kreativitas akan menjadi seni ketika seseorang melakukan kegiatan.

\section{Hasil Belajar}

Belajar merupakan faktor penyebab adanya perubahan yang terjadi pada diri suatu individu, yang mana ditimbulkan karena aktivitas-aktivitas individu itu sendiri. Seseorang dikatakan telah belajar sesuatu kalau pada dirinya terjadi perubahan tertentu. Menurut Whiterington yang dikutip oleh Ngalim Purwanto (2002:86) "belajar merupakan suatu perubahan yang terjadi melalui latihan dan pengalaman".

Tanpa usaha untuk melakukan latihan dan memperoleh pengalaman, suatu potensi yang ada pada diri seseorang tidak akan mengalami perkembangan secara optimal. Seseorang dapat dikatakan belajar apabila termasuk ke dalam ciri-ciri sebagai berikut; 1) Adanya perubahan dalam bentuk tingkah laku. 2) Bertambahnya kecakapan dan keterampilan yang diakibatkan perubahan tersebut. 3) Perubahan yang terjadi sebagai akibat dari usaha yang disengaja (Surya Brata, 2004: 286)

Pengertian belajar yang sudah dikemukakan di atas, tidak hanya menyangkut pada perubahan tingkah laku, tetapi lebih mendasar adalah diperolehnya pengetahuan yang men-dorong seseorang melakukan perubahan tersebut. Menurut Crow dan Crow yang dikutip Usman Effendi(2004:101), belajar adalah "memperoleh kebiasaan-kebiasaan, pengetahuan dan sikap". Sedangkan Mahfudh Sholahudin yang mengutip dari Whiterington mengemukakan bahwa belajar adalah "suatu perubahan di dalam kepribadian, yang menyatakan diri sebagai suatu pola baru daripada reaksi yang berupa kecakapan, sikap, kebiasaan, kepandaian atau suatu pengertian".

Berdasarkan uraian tersebut di atas, dapat disimpulkan belajar adalah proses perubahan yang terjadi pada seseorang melalui interaksi yang dilakukan terhadap lingkungan sekitarnya setiap saat baik dalam bentuk latihan maupun pengalaman, yang mendorong ke arah perbaikan dalam bertindak dan berpikir, meliputi aspek kognitif (pengetahuan), afektif (sikap) dan psikomotor (keterampilan). Sehingga hasil belajar seharusnya dimaknai sebagai suatu yang utuh tidak hanya berupa pengetahuan semata.

Bloom seperti dikutip Abdurrahman mengklasifikasikan hasil belajar kepada perkembangan tiga ranah (domain), yakni ranah kognitif, ranah afektif, dan ranah psikomotoris. Ranah kognitif berkenaan dengan hasil belajar intelektual yang terdiri atas enam aspek, yaitu pengetahuan atau ingatan, pemahaman, aplikasi, analisis, sintesis, dan evaluasi. Kedua aspek pertama disebut disebut kognitif tingkat rendah dan keempat aspek berikutnya termasuk kognitif tingkat tinggi. Ranah afektif berkenaan dengan sikap yang terdiri dari lima aspek, yaitu penerimaan, jawaban dan reaksi, penilaian, organisasi dan internalisasi. Ranah psikomotoris berkenaan dengan hasil 
belajar keterampilan dan kemampuan bertindak. Ada enam aspek ranah psikomotoris, yaitu (a) gerakan reflek, (b) keterampilan gerakan dasar, (c) kemampuan perseptual, (d) keharmonisan dan ketepatan, (e) gerakkan keterampilan kompleks, dan (f) gerakan ekspresif dan interpretatif (Mulyono Abdurrahman: 98).

Ada dua perilaku khusus siswa yang telah teruji sebagai tolak ukur hasil pembelajaran (learning outcome), yaitu konsep diri akademis dan cita-cita terhadap pencapaian. Lebih dari itu, telah ditemukan hubungan yang signifikan antara perilakuperilaku siswa dengan tingkat pencapaian hasil ujiannya (performance). House mengemukakan:

"Wilhite found that students' academic self-concept was significant predictor in a multivariate analysis of college course performance. Students expectations for their academic achievement have been shown to be significant predictors of their subsequent grade performance" (Daniel J. House, 2006:257).

Dari pendapat di atas terlihat bahwa tingkat pencapaian siswa akan hasil belajarnya tidak terlepas dari konsep diri mereka tentang hasil akademis dan harapan (expectation) mereka untuk memperoleh hasil belajar. Konsekuensinya atas hasil belajar yakni, hasil belajar tidak hanya dipengaruhi oleh capaian seseorang tetapi juga oleh adanya ulangan penguatan (reinforcement) yang diberikan oleh lingkungan sosial, terutama guru atau orang tua. Oleh karena itu, pemberian ulangan penguatan yang wajar dan adil merupakan bagian yang sangat penting dalam kegiatan pembelajaran, lebih-lebih bagi anak berkesulitan belajar. Penjelasan Keller dalam Abdurrahman tentang berbagai faktor yang berpengaruh terhadap hasil belajar seperti yang dikemukakan di atas menunjukkan bahwa ia berusaha untuk menggabungkan variabel kognitif dengan variabel lingkungan dalam hubungannya dengan usaha, hasil belajar, dan konsekuensi. Dengan kata lain, Keller tampak berupaya memadukan teori-teori behavioristik dan kognitif untuk diterapkan dalam kegiatan pembelajaran

Berdasarkan keterangan-keterangan di atas, maka Ahmadi dan Prasetya merinci faktor-faktor yang mempengaruhi proses dan hasil belajar sebagai berikut: Faktor input (faktor murid/anak itu sendiri) di mana tiap anak memiliki kondisi yang berbedabeda dalam: (a) kondisi fisiologis (b) kondisi psikologis, (c)Faktor environmental (faktor lingkungan), baik itu lingkungan alami atau pun lingkungan sosial. Faktor instrumental input, yang di dalamnya antara lain terdiri dari: (a)Kurikulum, (b)Program/bahan pelajaran, (c)Sarana/fasilitas (d) Guru (tenaga pengajar). Dari sekian banyak faktor yang ada tersebut sebenarnya dapat dikerucutkan menjadi beberapa faktor saja yang penting misalnya Motivasi dan Kreatifitas. Hal tersebut karena daktor faktor seperti kondisi fisiologis, psikologis, dan enviromental memicu seseorang untuk termotivasi belajar. Sedangkan faktor-faktor seperti Kurikulum, bahan ajar, sarana, dan guru dapat memberikan dampat berkembanya kreatifitas anak.

\section{Kreatifitas Belajar}

Kreativitas seringkali dianggap sebagai sesuatu keterampilan yang didasarkan pada bakat alam, dimana hanya mereka yang berbakat saja yang bisa menjadi kreatif. Anggapan tersebut tidak sepenuhnya benar, walaupun dalam kenyataannya terlihat bahwa orang tertentu memiliki kemampuan untuk menciptakan ide baru dengan cepat dan beragam. Sesungguhnya kemampuan berpikir kreatif pada dasarnya dimiliki semua orang.

Menurut Satiadarma, kreativitas merupakan salah satu modal yang harus 
dimiliki siswa untuk mencapai prestasi belajar. Kreativitas siswa tidak seharusnya diartikan sebagai kemampuan menciptakan sesuatu yang benar-benar baru, akan tetapi kecerdasan yang dimiliki siswa dalam memandang ketentuan dimana masih perlu adanya bimbingan, pemahaman. Arti kreativitas yang dikenal dengan four p's of creativity, yakni person, process, press dan product. Kreativitas dari segi "pribadi" (person) menunjukkan pada potensi daya kreatif yang ada pada setiap pribadi. Kreativitas sebagai suatu "proses" (process) dapat dirumuskan sebagai suatu bentuk pemikiran dimana individu berusaha menemukan hubungan yang baru, mendapatkan jawaban, metode atau cara baru menghadapi masalah. Kreativitas sebagai "pendorong" (press) yang datang dari diri sendiri berupa hasrat dan motivasi yang kuat untuk berkreasi. Kreativitas dari segi "hasil" (product) segala sesuatu yang diciptakan seseorang sebagai hasil dari keunikan pribadinya dalam interaksi dengan lingkungannya.

Menurut

Munandar(2009:25)

"kreativitas sebagai kemampuan untuk menciptakan sesuatu yang baru, sebagai kemampuan untuk memberi gagasan baru yang dapat diterapkan dalam pemecahan masalah, atau sebagai kemampuan untuk melihat hubungan baru antara unsur yang sudah ada sebelumnya. Kreativitas seseorang dapat dilihat dari tingkah laku atau kegiatannya yang kreatif". Menurut Slameto (2003:146) bahwa "yang penting dalam kreativitas bukanlah penemuan sesuatu yang belum pernah diketahui orang sebelumnya, melainkan bahwa produk kreativitas merupakan sesuatu yang baru bagi diri sendiri dan tidak harus merupakan sesuatu yang baru bagi orang lain atau dunia pada umumnya".

Menurut Utami Munandar (2009:35) ada alasan mengapa kreativitas penting untuk dimunculkan, dipupuk dan dikembangkan dalam diri anak, antara lain: Pertama, dengan berkreasi anak dapat mewujudkan dirinya. Perwujudan diri adalah salah satu kebutuhan pokok manusia. Kedua, kemampuan berpikir kreatif dapat melihat berbagai macam penyelesaian suatu masalah. Mengekspresikan pikiran-pikiran yang berbeda dari orang lain tanpa dibatasi pada hakikatnya akan mampu melahirkan berbagai macam gagasan. Ketiga, bersibuk secara kreatif akan memberikan kepuasan kepada individu tersebut. Hal ini penting untuk diperhatikan karena tingkat ketercapaian kepuasan seseorang akan mempengaruhi perkembangan sosial emosinya. Keempat, dengan kreativitas memungkinkan manusia meningkatkan kualitas hidupnya.

Beberapa ciri-ciri kepribadian yang kreatif yaitu: 1) Rasa ingin tahu yang mendalam, 2) Sering mengajukan pertanyaan yang baik, 3) Memberikan banyak gagasan, 4) Bebas dalam menyampaikan pendapat, 5) Mempunyai rasa keindahan yang dalam, 6) Memiliki rasa humor yang luas, 7) Mempunyai daya imajinasi dan 8) Orisinal dalam mengungkapkan gagasan. 9) Menonjol dalam salah satu bidang seni (Munandar, 2009:25).

\section{Motivasi}

Para ahli berpendapat bahwa tingkah laku manusia didorong oleh motif-motif tertentu dan perbuatan belajar akan berhasil apabila didasarkan pada motivasi yang ada pada siswa. Siswa dapat dipaksa untuk mengikuti suatu perbuatan, tetapi ia tidak dapat dipaksa untuk menghayati perbuatan itu sebagaimana mestinya (Hamalik, 157).

Ada beberapa faktor yang dapat diidentifikasi oleh seorang guru agar dapat memotivasi siswa, yaitu: faktor waktu yang tersedia, jumlah siswa dan kebutuhan belajar dan emosionalnya, tuntutan pertanggungjawaban yang berat dari administrator dan orang tua serta situasisituasi lain yang merupakan tekanantekanan yang dijumpai di sekolah. Hal ini sangat menolong bagi guru-guru untuk 
mengetahui tentang apa dan bagaimana menemukan motivasi belajar yang alami yang dapat dikembangkan dan dicapai untuk memotivasi siswa. Pemahaman terhadap hal-hal tersebut di atas membantu guru untuk menyadari bahwa hampir semua yang dikerjakannya di dalam kelas memiliki pengaruh motivasi pada siswa baik positif atau pun negatif. Hal ini termasuk cara menyampaikan informasi, model aktivitas yang dipergunakan, cara guru berinteraksi dengan siswa, dan kesempatan bagi siswa untuk bekerja secara individu atau kelompok. Siswa akan bereaksi terhadap siapa guru tersebut, apa yang dilakukannya dan bagaimana mereka merasakan kenyamanan di dalam kelas (McCombs, 2016).

Motivasi merupakan proses yang tidak dapat diamati, tetapi ditafsirkan melalui tindakan individu yang bertingkah laku, sehingga motivasi merupakan konstruksi jiwa. Kedudukan motivasi sejajar dengan isi jiwa sebagai cipta (kognisi), karsa (konasi), dan rasa (emosi) yang merupakan tridaya. Apabila cipta, karsa dan rasa yang melekat pada diri seseorang dikombinasikan dengan motivasi dapat menjadi catur daya atau empat dorongan yang dapat mengarahkan individu untuk mencapai tujuan dan memenuhi kebutuhan.

Menurut McDonald motivasi adalah merupakan perubahan energi dalam diri (pribadi) seseorang yang ditandai oleh dorongan afektif dan reaksi-reaksi untuk mencapai tujuan. Di dalam perumusan pendapat Mc Donald tersebut di ini bila dicermati ada tiga unsur yang saling berkaitan, yaitu:

Motivasi dimulai dari adanya perubahan energi di dalam pribadi. Perubahan-perubahan dalam motivasi timbul dari perbuatan tertentu di

Motivasi ditandai dengan timbulnya perasaan affective arousal. Mula-mula merupakan ketegangan psikologis lalu merupakan suasana emosi. Suasana ini menimbulkan kelakuan yang bermotif Perubahanini bisa dan mungkin juga tidak, kita hanya dapat melihatnya dalam perbuatan.

Motivasi ditandai dengan reaksi-reaksi untuk mencapai tujuan. Pribadi yang bermotivasi mengadakan respons-respons yang tertuju ke arah suatu tujuan. Responsrespons itu berfungsi mengurangi ketegangan yang disebabkan oleh perubahan energi dalam dirinya. Setiap respons merupakan suatu langkah ke arah mencapai tujuan.

Psikolog Gestalt mengatakan bahwa motivasi merupakan produk dari ketidaksesuaian dari sebuah pase kehidupan. Dalam pase kehidupan itu meliputi tujuantujuan yang positif atau negatif yang ingin diraih atau dihindarkan. Artinya bahwa motivasi itu timbul akibat adanya dorongan-dorongan lain yang ada dalam organisme. Morris L. Bigger (1982) mengatakan bahwa "organism drives such as hunger, thirst and sexual need; and for emotionals such as fear, anger and love produce behaviors that predictable and irresistible. "

Selanjutnya ahli perilaku (behavioriest) berpendapat bahwa motivasi adalah dorongan untuk berbuat sesuatu sebagai akibat adanya rangsangan yang mendahuluinya. Seluruh motivasi timbul secara langsung dari dorongan-dorongan organisme, emosi-emosi dasar atau dari kecenderungan untuk merespons terhadap dorongan-dorongan dan emosi-emosi tersebut. Dorongan organisme seperti lapar, haus dan kebutuhan seksual (sexual need) dan dorongan emosi seperti rasa takut, marah keduanya membentuk tingkah laku (behavior) yang dapat diprediksi.

Berdasarkan pendapat di atas dapat dipahami bahwa tingkah laku yang tampak pada diri seseorang itu dipengaruhi oleh stimulus-stimulus dari dalam dan dari luar diri manusia. Seperti rasa lapar, haus, 
kebutuhan seksual, takut, marah, cinta dan lain-lain. Stimulus-stimulus inilah merupakan motif atau dorongan yang mempengaruhi motivasi dan daya kreatifitas dari seseorang untuk menghasilkan suatu karya.

\section{METODE}

Metode penelitian yang dipergunakan dalam penelitian ini adalah metode survey dengan teknik korelasional.

\section{Jenis Penelitian}

Jenis penelitian yang berupaya untuk mengemukakan ada tidaknya hubungan variabel bebas dengan variabel terikat. Variabel penelitian terdiri dari dua variabel bebas dan satu variabel terikat. Variabel bebas adalah motivasi siswa (X1) dan kreativitas belajar (X2), sedangkan variabel terikat adalah hasil belajar PKn siswa (Y).

\section{Waktu dan Tempat Penelitian}

Penelitian dilakukan di lakukan di semua SMK Swasta yang berada di Kabupaten Bogor Provinsi Jawa barat

\section{Subjek Penelitian}

Subjek penelitian yakni sebanyak 140 siswa yang kemudian di ambil sample dengan mendasarkan pada Teori Slovin sebagaimana dikutip oleh Felina dalam bukunya Sumber Daya Manusia dalam Organisasi (1998) menyebutkan bahwa dalam menentukan sampel untuk penelitian yang diambil dari populasi adalah mengikuti rumus berikut ini.

$$
\begin{aligned}
& \mathbf{n}=\frac{n}{1+N e^{2}} \\
& \mathrm{n}=\text { ukuran sampel; } \\
& \mathrm{N}=\text { jumlah populasi dan } \\
& \mathrm{e}=\text { derajat kelonggaran } \\
& \text { ketidaktelitian karena kesalahan } \\
& 1+\frac{140}{40 \times 0,015}
\end{aligned}
$$
ditoleransi, misalnya $15 \%$.

Jumlah Sampel :

$$
\begin{gathered}
\frac{140}{3,1} \\
45,16
\end{gathered}
$$

Jadi, sampel yang dipakai adalah 45 orang

\section{Prosedur}

Prosedur perlu dijabarkan menurut tipe penelitiannya. Bagaimana penelitian dilakukan dan data akan diperoleh, perlu diuraikan dalam bagian ini.

Untuk penelitian eksperimental, jenis rancangan (experimental design) yang digunakan sebaiknya dituliskan di bagian in.

\section{Data, Intrumen, dan Teknik Pengumpulan Data}

Instrumen yang digunakan pada penelitian ini berupa pilihan ganda dan disusun berdasarkan atas indikator-indikator yang telah ditetapkan sehingga menghasilkan sebanyak 50 pertanyaan dalam bentuk pilihan ganda (PG). Untuk menguji kesahihan butir instrumen tersebut sebelumnya telah dilakukan uji coba instrumen kepada 30 siswa kelas XI SMK Swasta di Kecamatan Cibinong Kabupaten Bogor Provinsi Jawa Barat yang tidak termasuk sampel. Uji instrumen tersebut meliputi uji Validitas dan Uji Reliabilitas.

Uji validitas dilakukan dengan menggunakan rumus point biserial correlation (rpbis), yaitu:

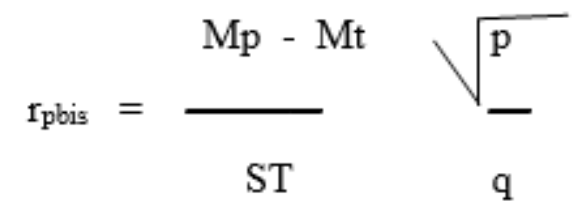

Keterangan:

$$
\begin{aligned}
\text { rpbis }= & \text { Koefisien Korelasi Point Biserial } \\
\mathrm{Mp}= & \text { Mean skor subjek-subjek yang } \\
& \text { menjawab benar } \\
\mathrm{Mt} \quad= & \text { Mean skor total }
\end{aligned}
$$


ST $=$ Standar deviasi skor total

$\mathrm{P} \quad=$ Proporsi subjek yang menjawab benar

$\mathrm{q}=$ Proporsi subjek yang menjawab salah

Kriteria yang digunakan untuk uji validitas butir mengunakan rujukan $r$ tabel dengan $\alpha=0,05$, jika rhitung lebih besar dari atau sama dengan rtabel, maka butir instrumen dianggap valid. Sebaliknyajika rhitung lebih kecil dari pada rtabel maka butir instrumen tidak valid dan selanjutnya didrop atau tidak digunakan.

Keterandalan (reliability) instrumen dalam penelitian hasil belajar PKn pada materi menghargai persamaan kedudukan warga negara dalam berbagai aspek kehidupan menggunakan rumus $\mathrm{K}-\mathrm{R} 20$, yaitu dengan mencari total varians instrumen (yang memenuhi kriteria valid), dan total varians butir dari seluruh instrumen (termasuk butir yang valid dan butir yang drop), kemudian menghitung reliabilitas instrumen ke dalam rumus $\mathrm{K}-\mathrm{R}$ 20. Uji reliabilitas ini dilaksanakan terhadap 30 siswa diluar sampel dalam populasi dengan menggunakan rumus $\mathrm{K}-\mathrm{R} 20$, yaitu:

$$
\mathrm{rll}=(\underbrace{\mathrm{K}}_{\mathrm{K}-1}) \underbrace{(\mathrm{Vt}-\Sigma \mathrm{pq}}_{\mathrm{Vt}})
$$

Keterangan:

r11 = Reabilitas instrumen

$\mathrm{K} \quad$ = Banyak butir soal yang valid

$\mathrm{Vt}=$ Varian total

$\mathrm{P} \quad=$ Proporsi subjek yang menjawab benar

$\mathrm{q}=$ Proporsi subjek yang menjawab salah
Kriteria pengujian dikonsultasikan dengan $r$ product moment dengan taraf signifikansi $0,05(5 \%)$, jika rhitung lebih dari atau sama dengan rtabel maka instrumen dinyatakan reliabel. Begitu pula sebaliknya, jika rhitung kurang dari $r$ tabel maka instrumen dinyatakan tidak reliabel.

\section{Teknik Analisis Data}

Data yang diperoleh dari hasil penelitian dianalisis dengan menggunakan analisis statistik deskriptif dan analisis statistik inferensial. Analisis statistik deskriptif digunakan untuk mengetahui harga skor maksimum, skor minimum, jangkauan (range), mean, median, modus, standar deviasi dan varians masing-masing variabel. Selanjutnya hasil perhitungan tersebut dideskripsikan dalam daftar frekuensi masing-masing variabel yang kemudian divisualkan dalam bentuk histogram. Sedangkan analisis statistik inferensial diperlukan untuk pengujian hipotesis dan generalisasi penelitian.

Sebelum dilakukan pengujian hipotesis, terlebih dahulu dilakukan pengujian prasyarat analisis yang terdiri dari uji normalitas galat taksiran dan uji homogenitas varians. Uji normalitas galat taksiran dilakukan dengan menggunakan teknik Lilliefors, sedangkan uji homogenitas varians dilakukan dengan uji Barlett.

\section{HASIL DAN PEMBAHASAN}

Dari hasil analisis data maka dapat diketahui bahwa besarnya variasi perubahan Hasil Belajar yang mampu dijelaskan oleh Motivasi Siswa yang dimasukkan dalam model persamaan regresi sederhana mencapai sekitar 37,90\%, sedangkan sisanya sebesar $62,10 \%$ dipengaruhi dari variabel bebas lain yang tidak dimasukkan ke dalam model persamaan regresi sederhana dan tidak diteliti, sehingga Motivasi Belajar memiliki kemampuan cukup tinggi menjelaskan Hasil Belajar . 
Besarnya variasi perubahan Hasil Belajar yang mampu dijelaskan oleh Kreativitas Belajar yang dimasukkan dalam model persamaan regresi sederhana mencapai sekitar 59,40\%, sedangkan sisanya sebesar $40,60 \%$ dipengaruhi dari variabel bebas lain yang tidak dimasukkan ke dalam model persamaan regresi sederhana dan tidak diteliti, sehingga Kreativitas Belajar memiliki kemampuan tinggi menjelaskan Hasil Belajar .

Besarnya variasi perubahan Hasil Belajar yang mampu dijelaskan oleh Motivasi Siswa dan Kreativitas Belajar secara bersama-sama yang dimasukkan dalam model persamaan regresi ganda mencapai sekitar 52,20\%, sedangkan sisanya sebesar $47,80 \%$ dipengaruhi dari variabel bebas lain yang tidak dimasukkan ke dalam model persamaan regresi ganda dan tidak diteliti, sehingga Motivasi Belajar dan Kreativitas Belajar secara bersamasama memiliki kemampuan sangat tinggi menjelaskan Hasil Belajar .

Diantara variabel-variabel bebas dalam penelitian ini, maka variabel bebas yang sangat dominan mempengaruhi Hasil Belajar di SMK Swasta Kecamatan Cibinong Kabupaten Bogor adalah Kreativitas Belajar.

\section{SIMPULAN DAN SARAN}

\section{Simpulan}

Berdasarkan hasil penelitian dan pembahasan, kesimpulan yang didapat adalah sebagai berikut:

Motivasi Siswa berpengaruh cukup terhadap Hasil Belajar di SMK Swasta di Kecamatan Cibinong Kabupaten Bogor, dengan nilai korelasi sebesar 0,616. Dengan model persamaan regresi linear sederhana yang didapat adalah $\hat{\mathrm{Y}}=28,813+0,081 \mathrm{X} 1$ maka jika setiap Motivasi Siswa ditingkatkan sebanyak 1 unit, akan selalu terjadi selisih kenaikan Hasil Belajar sebanyak 0,081 unit. Besarnya variasi perubahan Hasil Belajar yang mampu dijelaskan oleh Motivasi Siswa mencapai sekitar 37,90\%, sedangkan sisanya sebesar $62,10 \%$ dipengaruhi dari variabel bebas lain yang tidak dimasukkan ke dalam model persamaan regresi sederhana dan tidak diteliti, sehingga Motivasi Siswa memiliki kemampuan cukup tinggi dalam menjelaskan Hasil Belajar.

Kreativitas Belajar Siswa berpengaruh cukup terhadap Hasil Belajar di SMK Swasta di Kecamatan Cibinong Kabupaten Bogor, dengan nilai korelasi sebesar 0,771. Dengan model persamaan regresi linear sederhana yang didapat adalah $\hat{\mathrm{Y}}=38,770$ $+0,021 \mathrm{X} 2$, maka jika setiap kreativitas belajar ditingkatkan sebanyak 1 unit, akan selalu terjadi selisih kenaikan Hasil Belajar sebanyak 0,021 unit. Besarnya variasi perubahan Hasil Belajar yang mampu dijelaskan oleh kreativitas belajar mencapai sekitar 59,40\%, sedangkan sisanya sebesar $40,60 \%$ dipengaruhi dari variabel bebas lain yang tidak dimasukkan ke dalam model persamaan regresi sederhana dan tidak diteliti, sehingga kreativitas belajar memiliki kemampuan tinggi dalam menjelaskan Hasil Belajar.

Motivasi Siswa dan kreativitas belajar secara bersama-sama berpengaruh cukup terhadap Hasil Belajar di SMK Swasta di Kecamatan Cibinong Kabupaten Bogor, dengan nilai korelasi sebesar 0,723. Dengan model persamaan regresi linear ganda yang didapat adalah $\hat{\mathrm{Y}}=29,492+0,128 \mathrm{X} 1+$ 0,052 X2, maka jika setiap Motivasi Belajar dan kreativitas belajar secara bersama-sama ditingkatkan sebanyak 1 unit, akan selalu terjadi selisih kenaikan Hasil Belajar sebanyak 0,180 unit. Besarnya variasi perubahan Hasil Belajar yang mampu dijelaskan oleh Motivasi Siswa dan kreativitas belajar secara bersama-sama mencapai sekitar 52,20\%, sedangkan sisanya sebesar $47,80 \%$ dipengaruhi dari variabel bebas lain yang tidak dimasukkan ke dalam model persamaan regresi ganda dan tidak diteliti, sehingga Motivasi Siswa dan kreativitas belajar secara bersama-sama 
memiliki kemampuan sangat tinggi dalam menjelaskan Hasil Belajar.

\section{Saran}

Manajemen kurikulum SMK swasta di kecamatan Cibinong perlu memberikan formulasi belajar yang mampu menumbuhkan motivasi siswa dengan baik, dan memberikan keleluasaan siswa terlibat secara langsung dalam proses pemecahan masalah. Penulis memberikan saran agar ditingkatkan penggunaan medel pendekatan Cooperative Learning.

Profesionalisme guru perlu lebih ditingkatkan lagi guna menyediakan pengalaman pembelajaran yang menghasilkan kualitas kerja. Oleh karenanya, mereka perlu adanya diklat ketrampilam proses sehingga memacu kreativitas belajar siswa dan sekolah hendaknya menyediakan fasilitas belajar yang menadahi terutama belajar berbasis IT .

Manajemen sekolah perlu menentukan target mutu yang ingin dicapai setiap kurun waktu, merencanakan, melaksanakan dan evaluasi dirinya, untuk kemudian menentukan target mutu tahun berikutnya.

\section{DAFTAR PUSTAKA}

Abdurrahman, Mulyono. Pendidikan Bagi Anak Berkesulitan Belajar. Jakarta: Rineka Cipta, 2009.

Arikunto, Suharsimi. Manajemen Pengajaran Secara Manusiawi. Jakarta: Rineka Cipta, 2003

Bigge, Morris L. Learning Theories for Teachers. New York: Harper and Row, 2002.

Durden, William G. "Rediscovering SelfRelience in Education: The Optimal Match". Phi DeltaKappa, v 77, November 2005.

Dwi Prayitno, Penelitian Diskreptif, Jakarta : Aneka Ilmu, 2012
Effendi, E. Usman. Pengantar Psikologi Pendidikan. Bandung: Angkasa, 2004.

Felder, Richard Navigating the Bumpy Road to Student-Cenrtered Instruction. College teaching v 44 Spring), 2006.

Hamalik, Oemar. Proses Belajar Mengajar. Jakarta: Bumi Aksara, 2001.

House, Daniel J. "Relationship between Learner Attitude, Prior Achievement, and Performance in a General Education Course". Interntional Journal of Instructional Media v 23 no 3, 2006.

Makmun, Abin Syamsuddin. Psikologi Kependidikan. Bandung: Rosdakarya. 2001.

Mar'at, Samsunuwiyati. Psikologi Perkembangan. Bandung: PT Remaja Rosdakarya, 2006.

McCombs, Barbara L. "Understanding the Keys to Motivation to Learn". Internet, Kid Source Online, $\mathrm{h}$. 1 , diakses tanggal 12 Januari 2016.

McCombs, Barbara L. Understanding the Keys to Creativity to Learn. http://www.mcrel.orq/barbaran.a sp, Internet, diakses tanggal 12 Januari 2016.

Bigge, M. L. (1982). Learning theories for teachers. Harper \& Row.

McDonald, Frederick. Educational Psychology (Becaming an Educator). Boston: Houghton Mifflin Company, 2001.

Moh. Nasir, Metodologi Penelitian, Jakarta : BSI, 2003

Mulyasa, E. Menjadi Guru Profesional (Menciptakan Pembelajaran Kreatif dan Menyenangkan). Bandung Rosda Karya, 2010.

Munandar, Utami. Kreativitas dan Keberbakatan: Strategi 
Mewujudkan potensi Kreatif dan Bakat. Jakarta: Gramedia Pustaka Utama, 2004.

Munandar, Utami. Pengembangan Kreativitas Anak Berbakat. Jakarta: PT Rineka Cipta, 2009.

Nasution, S. Berbagai Pendekatan dalam Proses Belajar Mengajar. Jakarta: Bina Aksara, 2000.

Naglim Purwanto, Psikologi Pendidikan, Bandung : Remaja Karya, 2002

Pamilu, Anik. Mengembangkan Kreativitas dan Kecerdasan Anak. Yogyakarta: Citra Media, 2007.

Prasetya, Joko T. dan Ahmad, Abu. Strategi Belajar Mengajar. Bandung: Pustaka Setia, 2007.

Prawiroatmojo, Dendosurono. Teori Belajar. Jakarta: UN Jakarta, 2000.

Purwanto, Ngalim. Psikologi Pendidikan. Bandung: Remaja Karya, 2002.

Rachmawati, Yeni dan Kurniawati, Euis. Strategi Pengembangan Kreativitas pada Anak Usia Taman Kanak-kanak. Jakarta. Kencana Preanada Media, 2010.

Satiadarma, Monly. Mendidik Kecerdasan. Jakarta: Pustaka Populer Obor, 2003.

Semiawan, Conny R. Mengembangkan Kreativitas. Bandung: Remaja Rosdakarya, 2005.

Sholahuddin, Mahfudh. Pengantar Psikologi Pendidikan. Surabaya: Bina Ilmu, 2000.

Slameto. Belajar dan Faktor-faktor yang Mempengaruhinya. Jakarta: Rineka Cipta, 2003.

Soeitoe, Samuel. Psikologi Pendidikan. Jakarta: FEUI, 2002.
Sudjana, Nana. Penilaian Hasil Proses Belajar Mengajar. Bandung: Rosdakarya, 2008.

Suprihatin, S. (2017). PENGGUNAAN MEDIA PENGAJARAN UNTUK MENINGKATKAN PRESTASI BELAJAR MATA PELAJARAN Ppkn PADA SISWA KELAS X SEMESTER I SMK NEGERI 1 BENDO KECAMATAN BENDO KABUPATEN MAGETAN TAHUN AJARAN 2014/2015. Citizenship Jurnal Pancasila dan Kewarganegaraan, 3(2), 320333.

Sugiyono. Statistik untuk Penelitian. Bandung: Alfabeta, 2009.

Suharsini Arikunto, Manajemen Pengajaran Secara Manusiawi, Jakarta : Kinika Cipta, 2010

Suryabrata, Sumadi. Psikologi Pendidikan. Jakarta: Rajawali, 2004.

Soenarjo, S., Sari, S. D., \& Dwijayanto, D. (2017). Motivasi Belajar Terhadap Peningkatan Prestasi Belajar Siswa Pada Mata Pelajaran Pkn Siswa Kelas Viii Smp Negeri 2 Barat Semester Genap Tahun Pelajaran 2014/2015. Citizenship Jurnal Pancasila dan Kewarganegaraan, 3(2), 258266.

Tim Penyusun Kamus Besar Bahasa Indonesia, Kamus Besar Bahasa Indonesia. Jakarta: Balai Pustaka, 2005. 